\title{
EVALUATION OF RENEWABLE ENERGY INVESTMENTS FROM PUBLIC FINANCIAL INSTITUTIONS
}

\author{
Dominika Čeryová* , Jana Ladvenicová, Zuzana Bajusová
}

\author{
Slovak University of Agriculture in Nitra, Slovakia
}

\begin{abstract}
Renewable energy sources have become a compelling investment proposition, and investment into renewable power has grown in the recent years. Scale up renewable energy investment is critical to accelerate the global energy transformation and reap its many benefits, while achieving climate and development targets. Public finance institutions provide public money to support public and private sector projects as well as policies and programmes that serve the public good with economic, environmental, or social benefits. Several such institutions have been established and resourced with the aim of supporting renewable energy investments such as: international financial institutions, development finance institutions, local financial institutions, export credit agencies, and climate finance institutions. The main aim of this paper was to analyze the investments provided by this type of institutions in the renewable energy sector in the world with a specific focus on European Union member states in 2009-2016.
\end{abstract}

Keywords: renewable energy, public financial institutions, investments, European Union

\section{Introduction}

The use of renewable energy sources is increasing worldwide to achieve energy production sustainability. To reach this goal and mitigate climate changes, all energy sources must be optimally managed (Mohammed and Al-Bazi, 2021).

Energy that can be acquired from natural resources such as sunlight, wind, rain, tides, waves, and geothermal energy is called renewable energy. All naturally occurring energy sources which are repetitive and consistent in availability may be called renewable energy sources (Murty, 2017).

As stated by Gaduš (2019), the principles of minimizing costs with an integrated approach to the use of renewable energy sources and reducing greenhouse gas emissions are taken into account in the projection of the use of renewable energy.

Renewable energy sources are the highest guarantee of energy security of the state, region, regions of the EU through the diversification of own resources, which represent energy carriers. They represent continuity of supply - general availability of renewable sources of energy and constant renewability or positive impact on the environment and certainty of the use of renewable energy sources in all climatic conditions and geographical levels (Janíček et al., 2009).

Renewable energy has become an important choice to solve the energy crisis and environmental problems. A sustainable development needs policies and strategies, which can improve energy efficiency and reduce greenhouse gas emissions (Li et al., 2020).

Renewable energy is the solution for the huge challenges of the $21^{\text {st }}$ century: they provide long-term energy security for developed and for developing countries, they trigger sustainable growth with a huge amount of future oriented jobs, they help mitigate climate change with a mix of decentralized and large-scale technologies (Hinrichs-Rahlwes, 2013).

The development of alternative energy is considered as one of the ways to reduce the environmental pollution and carbon dioxide emissions. The role of alternative energy has been determined since it helps to reduce greenhouse gas emissions and prevent climate change. In the world, this determines the development, considering international agreements and the implementation of the national policies of many states in this regard (Kapitonov et al., 2021).
EU member states have committed themselves to reducing greenhouse gas emissions by $20 \%$ by the end of 2020 , renewables will account for $20 \%$ of final energy consumption and $10 \%$ of transport consumption, energy consumption will be reduced by $20 \%$ compared to the 2007 forecast. To achieve these goals, it is necessary to limit the burning of fossil fuels, to prevent increasing deforestation, to cultivate the land, to manage waste, and to save energy. The transition to a low-carbon economy is not only a great opportunity but also a challenge to increase energy independence, the creation of new jobs as well as the development of science and research (Ministry of Environment of the Slovak Republic). Renewable energy production has many benefits, mainly environmental and economic. Moreover, the social aspects associated with it cannot be ignored. The use of renewable energy itself directly affects the improvement of the environment, which in turn has a positive effect on people (Czekala, Tarkowski and Pochwatka, 2021). In the present time in the industry, in municipal activities as well as in households there dominates the consumption of fossil fuels: coal, oil, and natural gas. In the world the use and consumption of energy is rising every year. At present and in the nearby future as well, people will have to draw attention to all types of energy, in particular, it refers to renewable energy sources (Valent, 2017).

In their study, authors Hao and Shao (2021) search some potential driving forces of renewable energy development. The authors analyze panel data from 118 countries worldwide during the period from 1995 to 2015. The results show that countries that are more vulnerable to climate change and have less carbon-intensive economies deploy higher shares of renewable energy in their total energy consumption. The findings show that countries become more supportive of renewable energy when their economies are less intertwined with fossil fuels and when relevant policies are in place to provide incentives on renewable energy sources.

Energy demand and supply patterns can be altered with the development of renewable energy on a large scale. This is a major challenge that demands comprehensive and sustainable solutions. Clean energy technologies are vital to alleviating poverty, expanding rural development, and maintaining environmental quality. The productive use of renewable energy in rural areas helps raise income and improve health, providing power to pump water for irrigation, to process crops, to power cottage industries and to light homes, schools, and hospitals - all services of first importance. 
Advanced technologies for new renewable power generation integrated with smart grids have been tested and proven in the field. If optimized and applied widely around the world, these technologies will generate substantial economic and environmental benefits (Global Environmental Facility, 2012).

\section{Material and methods}

The main aim of this paper was to analyze the investments provided by public financial institutions in the renewable energy sector in the world with a specific focus on European Union member states in 2009-2016.

The objects of the research were renewable energy sources (hydropower + wind energy + solar energy + energy from biomass and geothermal energy) in the world and the European Union.

Data - investments from public financial institutions - from the International Renewable Energy Agency (IRENA) were used (recorded based on conditions and policies applied in each country).

\section{Results and discussion}

\section{Investments provided by public financial institutions - world}

During the period under the review (2009-2016), public financial institutions invested 155,413 million dollars into the renewable energy sector worldwide. The situation is shown in more detail in the following table (see Table 1).

The largest share of money invested in the renewable energy sector falls on America - especially the wind energy sector (44.54\%). This mentioned share includes investments of North, South, Central America and the Caribbean. The largest amount is South America, which corresponds to about 93\% of the whole America's investments. In second place, there is Europe (21.84\%), followed by Asia (17.23\%), Africa (15.66\%), Eurasia (0.49\%) and Australia, Oceania (0.25\%) - see Figure 1.

Based on the RECAI - Renewable Energy Country Attractiveness Index (2017), China is the most attractive country in terms of investing in renewable energy sources in 2016. India came in second and the United States came in third. When it comes to investing only within public financial institutions, the largest percentage of investments in renewable energy worldwide accounted for America (RENEWABLES, Global Status Report, 2017), which is confirmed by the results of the paper, which shows that in 2016, America accounted for $32.28 \%$ of public financial investment and during the entire period 20092016 it was up to $44.54 \%$ share.

of the stated amount of invested money (155,412.4 million dollars), hydropower accounted for the largest percentage (49.81\%) during the

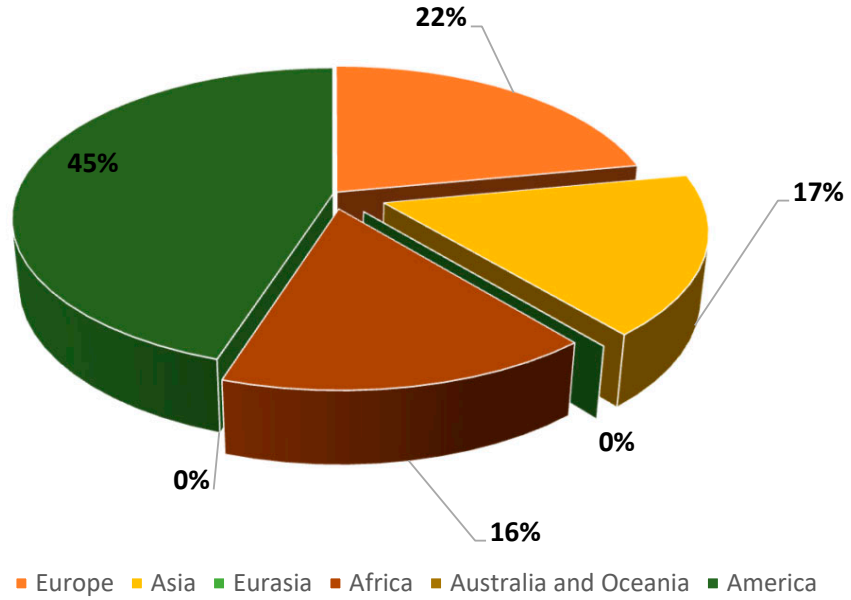

Figure 1 Investments provided by public financial institutions in 20092016 - world Source: own processing (IRENA - database)

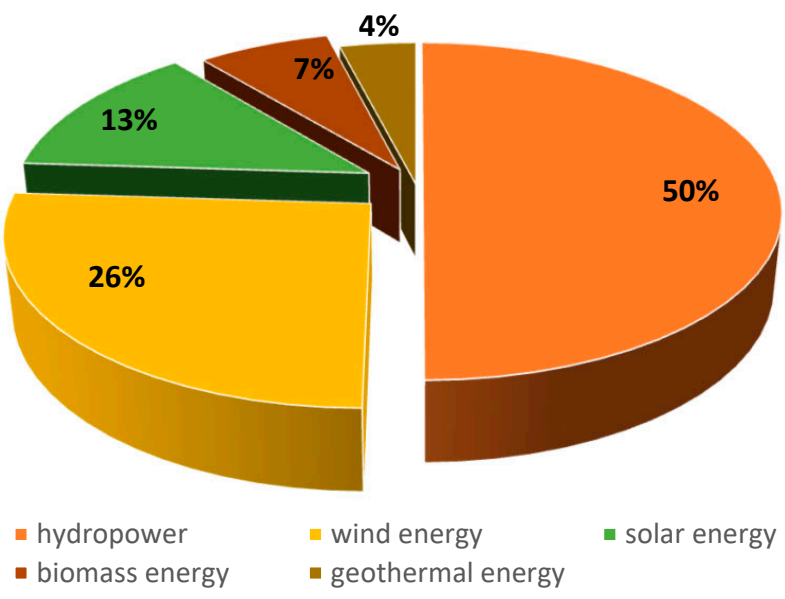

Figure 2 Investments provided by public financial institutions in 20092016 - technologies Source: own processing (IRENA - database)

monitored period. It was followed by wind energy (25.97\%) and solar energy (12.89\%). The smallest share was represented by the biomass energy sector (7.62\%) and the geothermal energy sector (3.71\%).

Table 1 Investments provided by public financial institutions in 2009-2016 - world

\begin{tabular}{|c|c|c|}
\hline & \multicolumn{2}{|c|}{ Investments provided by public financial institutions } \\
\hline & million dollars & $\%$ \\
\hline America & $69,216.12$ & 44.54 \\
\hline Europe & $33,944.24$ & 21.84 \\
\hline Asia & $26,773.47$ & 17.23 \\
\hline Africa & $24,332.62$ & 15.65 \\
\hline Eurasia & 756.4606 & 0.49 \\
\hline Australia and Oceania & 389.4834 & 0.25 \\
\hline World & $155,412.394$ & 100.00 \\
\hline
\end{tabular}

Source: own processing (IRENA - database) 


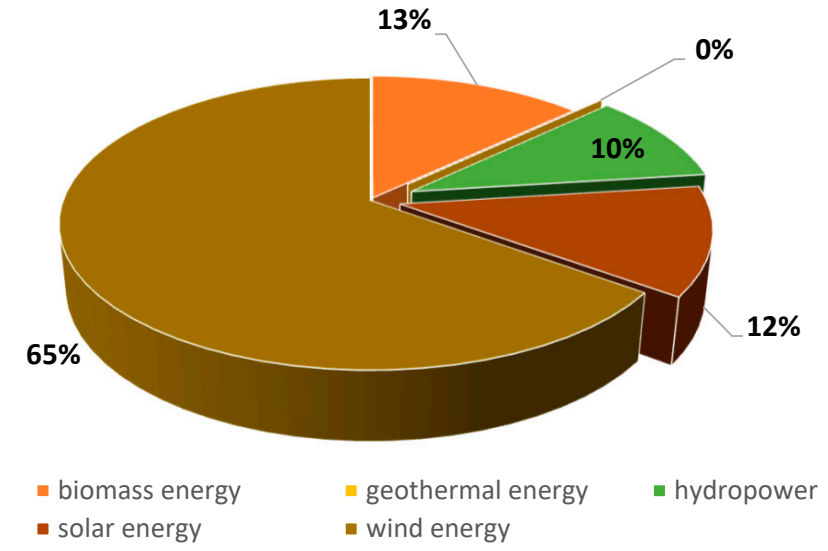

Figure 3 Investments provided by public financial institutions in 20092016 European Union - technologies Source: own processing (IRENA - database)

\section{Investments provided by public financial institutions - European Union}

In Europe (which is in second place in investment from public financial institutions - see the previous Table 1), money was invested from public financial institutions in the amount of 33,944.24 million dollars. The member states of the European Union (EU-27 and EU-28) accounted for up to around $90 \%$ of this amount. Another $10 \%$ is in the European Union's candidate and potential candidate countries and the rest of Europe (Asian countries that are sometimes included in Europe were excluded from observation and included in a separate area - Eurasia).

The situation in the European Union and in the world differs in terms of the investment from public financial institutions into individual renewable energy technologies. In the European Union, the largest share of investments was invested in the wind energy sector $-65.17 \%$. Germans, Belgians, Poles, and Austrians invest in the mentioned sector from all member states of the European Union, e.g. the wind energy sector is followed (in that order) by the biomass energy sector (13.31\%), the solar energy sector (11.58\%) and the hydropower sector (9.72\%). For comparison, the hydropower sector was in the largest percentage in terms of investment by public financial institutions in the world. Investments in geothermal energy represent only a $0.21 \%$ share.

The European Investment Bank (EIB), based in Luxembourg, the capital of Luxembourg, provides the largest amount of funding to the EU member states for renewable energy technologies. One of the European Investment Bank's main aim is to support action on climate change. Within the European

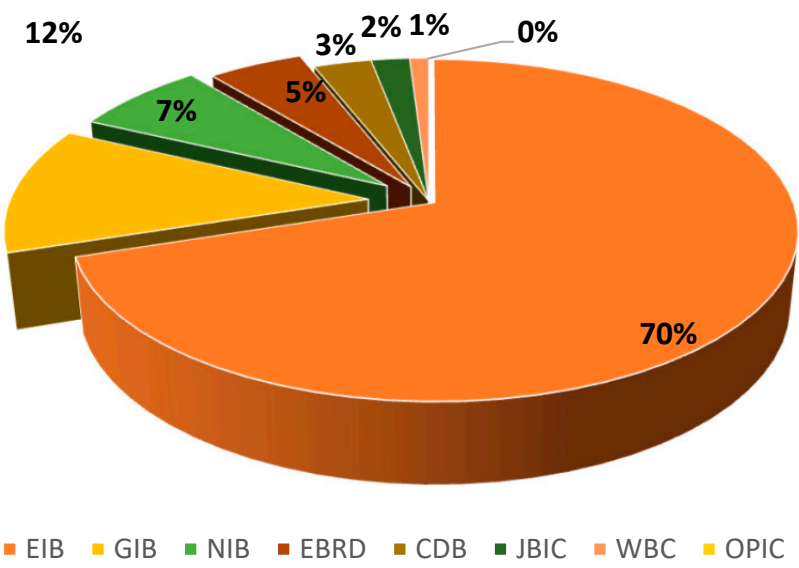

Figure 4 The most important public financial institutions investing in renewable energy sources within the countries of the European Union in 2009-2016 Source: own processing (IRENA - database)

Union, it accounts for up to $70.43 \%$ of all public financial institutions that support the renewable energy sector by providing funding. It provides loans to the EU member states that are tailored to the specific requirements of the investment project in the field of investment in hydropower, wind energy, solar energy, energy from biomass and heat-thermal energy. The most funds provided by all public financial institutions listed in the table (see Table 2) are mainly in the form of the already mentioned loans (up to $87.82 \%$ ). The percentage share of individual public financial institutions in the field of support for renewable energy technologies is clearly shown in the following graph (see Figure 4).

\section{Conclusions}

Scaling up renewable energy calls for mobilizing a massive investment increase. Renewable energy sources bring far reaching benefits in terms of human health, energy access, environmental protection, and the response to climate change. Global financial investment in renewables has remained far below its potential because of market barriers and perceptions of high risk that deters private investors and financiers. Throughout the period under review, the EU member states invested EUR 155,412 million in renewable energy from public financial institutions. The largest share of this amount was accounted for by America (44.54\%) and Europe (21.84\%). In the world, in terms of public investment, the largest amount is provided to the hydropower

Table 2 The most important public financial institutions investing in renewable energy sources within the countries of the European Union in 2009-2016

\begin{tabular}{|l|c|c|c|}
\hline & & million dollars \\
\hline EIB & European Investment Bank & $21,705.64$ \\
\hline GIB & Green Investment Bank & $3,612.771$ \\
\hline NIB & National Investment Bank & $2,205.73$ \\
\hline EBRD & European Bank for Reconstruction and Development & 11.72 \\
\hline CDB & Caribbean Development Bank & $1,600.817$ \\
\hline JBIC & Japan Bank for International Cooperation & 2.17 \\
\hline WBG & World Bank Group & 5.19 \\
\hline OPIC & Overseas Private Investment Corporation & 1.76 \\
\hline
\end{tabular}

Source: own processing (IRENA - database) 
sector. The European Union has a share of up to $90 \%$ in Europe. The situation differs from a technological point of view, as the European Union, unlike the whole world, invests in the wind energy sector. The European Investment Bank (EIB) provides the most funding from public financial institutions to the renewable energy sector within the European Union in the form of loans.

\section{References}

CZEKALA, W. - TARKOWSKI, F. - POCHWATKA, P. 2021. Social Aspects of Energy Production from Renewable Soruces. In Problemy Ekorozwoju, vol.16, 2021, no. 1, pp. 61-66.

GADUŠ, J. 2019. The impact of european and slovak legislation on development of regional bioenergy. Praha :Verbum, 2019, 172 p. ISBN 978-80-87800-61-4.

GLOBAL ENVIRONMENTAL FACILITY. 2012. Investing in renewable energy, the GEF experience. Proffesional Graphic Printing Co., 2012. ISBN 978-1-939339-49-2.

HAO, F. - SHAO, W. 2021. What really drives the development of renewable energy? A global assessment of 118 countries. In Energy Research \& Social Science, vol. 72 , 2021. DOI: 10.1016/j.erss.2020.101880

HINRICHS-RAHLWES, R. 2013. Renewable energy: Paving the way towards sustainable energy security: Lessons learnt from Germany. In Renewable Energy, vol. 49, 2013, pp. 10-14. D0l: 10.1016/j.renene.2012.01.076

JANÍČEK, F. et al. 2009. Renewable energy sources. 1, Technologies for a sustainable future. $2^{\text {nd }}$ ed., Bratislava : Renesans, 2009, 174 p. ISBN 978-80-89402-05-2.

KAPITONOV, I.A. - VOLOSHIN, V.I. - FILOSOFOVA, T.G. - SYRTSOV, D.N. 2021. Development of experience in the application of technologies in the field of alternative energy: World experience, Russian practice. In Renewable Energy, vol. 165, 2021, pp. 773782. D0l: 10.1016/j.renene.2020.11.063
LI, L. - LIN, J. - WU, N. - XIE, S. - MENG, CH. - ZHENG, Y. - WANG, X. - ZHAO, Y. 2020. Review and outlook on the international renewable energy development. In Energy and Built Environment, vol. 17, 2020, no. 12, pp. 1-19. D0I: 10.1016/j. enbenv.2020.12.002

MINISTRY OF ENVIRONMENT OF THE SLOVAK REPUBLIC. Renewable energy sources. Available online: https://www.minzp.sk//lima/obnovitelne-zdroje-energie/

MOHAMMED, N.A. - AL-BAZI, A. 2021. Management of renewable energy production and distribution planning using agent-based modelling. In Renewable Energy, vol. 164, 2021, pp. 509-520. D0I: 10.1016/j.renene.2020.08.0159

MURTY, P.S.R. 2017. Electrical Power Systems. Butterworth-Heinemann, 2017, pp. $783-$ 800. D0I:10.1016/B978-0-08-101124-9.00024-3

RENEWABLES. 2017. Global status report. Available online: https://www.ren21.net Reviews [online].

VALENT, V. 2017. Energy, Renewable Energy Sources and Household. In Proceeding of the $17^{\text {th }}$ International Conference "Management of Environment". Bratislava, 2017, pp.139-150. Available online: https://www.sszp.eu/wp-content/uploads/2017 conference MaZP $\mathrm{p}$-139 Valent5 f41.pdf

\section{Contact address}

Dominika Čeryová, Slovak University of Agriculture in Nitra, Faculty of Economics and Management, Department of Economics, Slovakia; e-mail: dominika.ceryova@uniag.sk 